\title{
INNOVATIONS WHICH BETRAY ARCHAISMS
}

1. Linguistic reconstruction is primarily based on the comparative method. It has long been recognized that this does not mean the simple projection of corresponding forms from the historically attested material into the proto-language. The reconstruction must be based on the older layers in the material, which manifest themselves more often in surviving anomalies than in regular forms. The elimination of anomalies in the course of time diminishes the value of the material for comparative purposes. We must therefore ask ourselves if lost categories are perhaps reflected in an indirect way.

Analogic change requires a model and a motivation. While analogic developments tend to obliterate the earlier linguistic system, they are themselves dependent upon the initial conditions. If the initial conditions have been lost, they may still be recoverable on the basis of the output which the analogic developments have produced. It goes without saying that this method can only be used in those cases where some knowledge of the earlier linguistic system is available. In particular, it may be useful for the establishment of the relative chronology of morphological innovations. In this paper I intend to present a few examples of the kind of analysis which $I$ have in mind.

My first example is the reconstruction of the Proto-Baltic demonstrative pronoun on the basis of the Old Prussian evidence. Van Wijk has argued that Prussian stas is a contamination of *sa and *tas (1918:111). In Proto-Indo-European, the pronominal stem *to- was in complementary distribution with the nom. sg. forms masc. *so, fem. *sā. As in Lithuanian, the oblique cases gave rise to competing nom. sg. forms masc. *tas, fem. *tã. The masc. form has been preserved in the 3sg ending - $t$ s of astits 'is', billatts 'spoke'. Van Wijk compares the subsequent contamination of *sa and *tas with the creation of OHG. bim 'am', which originated from a contamination of *im and *biju (OE. béo). Eventually, initial st- spread to the other forms of the paradigm.

Turning around the evidence, we can conclude from the creation of Old Prussian stas that the suppletive nom. sg. forms *so and *sä had been preserved in early Prussian and, consequently, in the Balto-Slavic proto-language. The contamina- 
tion of *sa and *tas cannot have been very recent because initial st-spread to the adverbial forms stwi, stwen, stwendau '(from) there'. On the other hand, the creation of *tas was probably posterior to the disintegration of the Balto-Slavic proto-language. The existence of Lith. tàs does not carry much weight because it can easily have originated from a parallel development, as is the case with the German equivalent der. More important is the fact that the stem *ono-provides suppletive nominative forms for the pronominal stem $*_{i}(0)$ - in both Slavic and Old Lithuanian (cf. Van Wijk 1918: 116). Since the nom. pl. forms are probably secondary (ibidem: 125), we can assume for Balto-Slavic the same distribution here as in the case of *so, *să and *to-.

If the nom. sg. forms *so and *sa were preserved in Balto-Slavic, the question arises: when were they lost? In Prussian and East Baltic *sa was replaced with stas and tas, respectively. Though it cannot be proved that a form *tos never existed in Slavic, there is no evidence that it ever did. The OCS. nom. acc. sg. form $t \breve{u}$ reflects *tom, not *tos (cf. especially Leskien 1907, Illič-Svityč 1963: 131, Ebeling 1967: 581, Kortlandt 1978: 287). It can therefore be suggested that *so was eliminated together with the original nom. sg. ending *-os of the $o$-stems in Slavic. When final $*_{-s}$ was lost, the nom. and acc. sg. endings of the $i$ - and $u$-stems merged, e.g. OCS. petr, synü. It is probable that this merger evoked the replacement of nom. *so synŭ with acc. tŭ synŭ, which in its turn led to the replacement

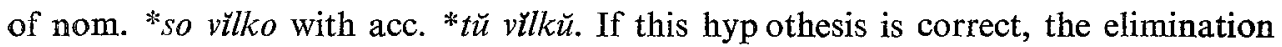
of *so can be dated to what I have called the Late Middle Slavic period (1979c: 263).

2. My second example concerns the reconstruction of the neuter gender in East Baltic on the basis of the Latvian evidence. It is generally assumed that there is no trace of the neuter in Latvian (e. g. Endzelin 1922: 291, Stang 1966: 179). In Lithuanian, survivals of the neuter are limited to predicative adjectives and adverbial forms of collective numerals.

As I1lič-Svityč has observed (1963: 154), there is a group of originally neuter $o$-stems which have broken intonation, indicating earlier accentual mobility, in Latvian, but fixed root stress in the more archaic varieties of both Lithuanian and Slavic. The relevant material is the following:

Latv. ấrkls 'plough', Lith. árklas, Ru. rálo, SCr. rälo, SIn. rálo, Cz. rádlo, Slk. radlo, Gr. áratron, Lat. arätrum.

Latv. kaûss 'scoop', Lith. káušas, Finn. kauha (loan word indicating original neuter gender).

Latv. krệsls 'chair', Lith. krëslas, OPr. creslan, Ru. kréslo, SCr. krèslo, Cz. kř́slo, křeslo. 
Latv. lûks 'bast', Lith. lùnkas, OPr. lunkan, Ru. lýko, SCr. likko, Sln. liko, Cz. lyko, Slk. lyko.

Latv. siêts 'sieve', Lith. sietas, $\mathrm{Ru}$. sito, $\mathrm{SCr}$. sïto, $\mathrm{Sln}$. sito, $\mathrm{Cz}$. sito, Slk. sito. Latv. vâks 'cover', Lith. vókas, Ru. véko, Sln. vẹ́ko, Cz. víko, Slk. veko.

The agreement between Slavic and Lithuanian leaves no doubt about the original fixed root stress in Balto-Slavic. Since the Latvian innovation did not affect original masculines, the neputer gender must have been preserved at a stage which was posterior to the separation of Latvian from Lithuanian. Elsewhere I have argued that the establishment of fixed stress on the initial syllable of the word is a recent development in the history of Latvian (1977: 328). Thus, we must assume a generalization of accentual mobility in neuter paradigms at a stage which was anterior to the fixation of the stress. This development has a parallel in modern Russian, where the majority of neuters with fixed root stress have passed to the mobile type (cf. Stang 1957: 82). Two words seem to have escaped the analogical transfer to the mobile paradigm in Latvian:

Latv. kaũls 'bone', Lith. káulas, OPr. caulan, Gr. kaulós.

Latv. tilts 'bridge', Lith. tiltas, Finn. silta (Ioan word indicating original neuter gender), Skt. tïrthäm.

These words may have become masculines at an earlier stage.

3. My third example is the reconstruction of the Baltic future on the basis of the Lithuanian accent pattern. It is a known fact that de Saussure's law does not operate in the future paradigm, e.g. tàpsiu, tàpsi 'I/ you will become'. Stang explains this accentuation as a generalization on the basis of tàps 'he / she / they will become' (1966: 471). It remains unclear why the generalization was limited to the future paradigm. Tamara Buch attributes this limitation to the influence of the infinitive and its derivatives (1970). I find such influence utterly improbable. It must be borne in mind that the more archaic dialects share the accentuation of the literary language, whereas instances of accentual mobility in the future paradigm are limited to dialects which characteristically generalize accentual mobility in the nominal system (cf. Zinkevičius 1966: 359). We must therefore conclude that the fixed stress is original and that de Saussure's law did not operate because the endings were not acute at that stage ${ }^{\mathrm{l}}$.

The acute endings $1 \mathrm{sg}-u(o)$ and $2 \mathrm{sg}-i(e)$ reflect the Proto-Indo-European primary thematic endings (cf. Kortlandt 1979a: 56f). In the athematic flexion, the acute intonation was originally confined to the $2 \mathrm{sg}$ form of the copula (ibidem: 58). Thus, we may conclude that the future had non-acute athematic endings at the stage when de Saussure's law operated. When the thematic present endings

1 My earlier suggestion that the forms were trisyllabic (1977: 328) cannot be maintained. 
were subsequently introduced into the future paradigm, the accent remained unchanged. Elsewhere I have shown that de Saussure's law is a comparatively recent development in the history of Lithuanian and did not operate in the other Baltic languages (1977: 327). This implies that much of the archaic character of the Lithuanian verbal system was lost during the last prehistoric centuries. I am not in a position to judge if the Old Lithuanian form eismi 'I will go' (Matusevičiutè 1938: 101) corroborates the position taken here, but the fast disappearance of the athematic present flexion since the 16th century suggests that it does.

Can we reconstruct the Proto-Baltic future paradigm? I think that the answer to this question rests heavily upon the interpretation of the Old Prussian material. Following Pedersen (1933: 7), I assume that teiks (45.3) is a 2 sg future form which is used imperativally. The same holds for endiris, engraudis, gerdaus $(2 \mathrm{x})$, engerdaus, and mijlis (read milijs). The plural forms powierptei, seggitei (3x), billitei, kirdijti $(2 \mathrm{x})$, laukijti, milijti, and dinkauti are easily explained as analogical formations on the basis of this $2 \mathrm{sg}$ form after the model of the original optative, which is also used as an imperative, e. g. gerbais, gerbaiti, immais, immaiti. These forms cannot be derived from either indicatives or optatives, cf. ind. 1pl etwërpimai, seggèmai, billēmai, kïrdimai, dīnkauimai, $2 \mathrm{pl}$ seggèti, turriti, rikauite, opt. segeitty ( $2 \mathrm{x}$ I), segeyti ( $2 \mathrm{x}$ II), kirdeiti, klausieiti, crixteiti. The usual identification of $k i r-$ deiti with kirdijti (e.g. Endzelin 1944: 185) cannot be correct because it requires two independent emendations. The similar identification of $2 \mathrm{sg}$ dereis with endi$r i s$ requires two more independent emendations. I think that the optative was formed from the present stem, as it is in Slavic, and that it must be separated from the forms under discussion.

On the basis of the Lithuanian and Prussian evidence I tentatively reconstruct the following Proto-Baltic paradigm:

$1 \mathrm{sg}$ eisim 'I will go' $1 \mathrm{pl}$ eisme
$2 \mathrm{sg}$ eis
$3 \mathrm{sg}$ eis

The $3 \mathrm{pl}$ form cannot be reconstructed. Endzelin suggested that the East Baltic connecting vowel $-i$ - was introduced from $3 \mathrm{pl} *$ eisin $<*^{*}$ eisnt $(1948: 185)^{2}$. This is only possible if the $3 \mathrm{pl}$ form had been preserved up to a comparatively recent stage. Moreover, it is not obvious that the ending should have zero grade rather than $*_{-e n}(t)$. The derivation of $-i$-from the $1 \mathrm{sg}$ ending seems preferable.

2 The same viewpoint is put forward ten years later by Schmalstieg (1958: 123f) and thirty years later by Jasan off (1978: 106), who does not mention Endzelin in spite of the fact that the latter's comparative grammar is readily available in English. 
Holger Pedersen has shown that the forms established here replace the following Proto-Indo-European paradigm (1921:26 and 1933: 19):

$\begin{array}{ll}1 \mathrm{sg} \text { iesmi } & 1 \mathrm{pl} \text { ismes } \\ 2 \mathrm{sg} \text { ies }(s) i & 2 \mathrm{pl} \text { iste } \\ 3 \mathrm{sg} \text { iesti } & 3 \mathrm{pl} \text { isenti }\end{array}$

The proposed reconstruction differs from this paradigm in two respects: it has normal grade in the root and secondary instead of primary endings. The normalization of the root vocalism is to be expected, but the introduction of secondary endings is no trivial development. It is best explained by the assumption that the Proto-Baltic paradigm established here was a subjunctive mood rather than a future tense and that the secondary endings were taken from the optative ${ }^{3}$. In East Baltic, this subjunctive developed into a future indicative. In Old Prussian, both the subjunctive and the optative assumed the function of an imperative. This language created a future indicative by the addition of the regular present endings to the subjunctive stem, as is evident from $2 \mathrm{sg}$ postäsei 'you will become' $(2 \mathrm{x})$. The form etskisai (51.11), which translates 'fehrest', is an athematic present form because the ending -sai belongs to the athematic present. The optative ending -sei, e.g. in boüsei, must be derived from a $3 \mathrm{sg}$ opt. form of the copula *sei and cannot be identified with the future paradigm (cf. Van Wijk 1929:159f).

4. It may be expedient to add a short note on the optative endings of the Old Prussian imperative. As a rule, the endings are -ais, -aiti with thematic verbs and stems in $-\bar{a}$-, and -eis, -eiti with athematic verbs and stems in $-i \bar{l} / i(e)$ - (cf. Stang 1966: 437f). It seems to have remained unnoticed that in the latter category the preceding $i$ was lost if the root vowel was front but preserved if it was back: crixteiti, kirdeiti, dereis, tenseiti, etwerreis, etwerpeis versus klausieiti, draudieiti, poieiti, pokuntieis, also dellieis (Lith. dalyti), where the rise of $e$ from $a$ was posterior to the progressive accent shift (cf. Kortlandt 1974: 303). The elimination of the $i$ in isrankeis and poskuleis may be secondary, as is the extension of -eis to the thematic flexion.

If the loss of antevocalic $i$ after a syllable with a front vowel is a phonetic develppment, it offers an explanation for the difference between the article and the pronoun to which Van Wijk has called attention (1918: 94): fem. gen. sg. stesses (steises) 'the', stessies (stessias) 'she', dat. sg. stessei (steisei) 'the', stessiei (stei-

${ }^{3}$ Similarly, the Old Irish future must be derived from a subjunctive with secondary endings, as I have argued elsewhere (1979b: 49). There is no reason to assume the existence of a thematic subjunctive at any stage in the history of Balto-Slavic (cf. in this connection Lane 1959).

4 This view is unjustly disregarded by Schmid (1963: 51), who does not even mention Van Wijk in this connection though he refers to his article four times on the three adjoining pages. 
siei) 'she'. The article must now be compared with Skt. asyás, asyái < *esiās, $-\bar{a} i$, the pronoun with tásyãs, tásyai < ${ }^{*}$ tosiās, $-\bar{a} i$. The masc. gen. sg. form stesset (also steisei, but never -siei) must be compared with Skt. asyá <*esio, not with tásya, Gr. toino. This confirms Van Wijk's perspicacious hypothesis that the Proto-Indo-European pronominal stem *e- survived in Balto-Slavic (ibidem: 121).

\section{REFERENCES}

Buch T. 1970 Zur Akzentuierung des Futurums im Litauischen.- In: Donum Balticum Stockholm, S. $77-82$.

Ebeling C. L. 1967 Historical laws of Slavic accentuation. - In: To Honor Roman Jakobson. The Hague, p. 577-593.

Endzelin J. 1922 Lettische Grammatik. - Riga. 1944 Altpreussische Grammatik. - Riga. 1948 Baltu valodu skaṇas un formas. - Riga.

Illið̌-Svityč V. M. 1963 Именная акцентуация в балтийском и славянском. - M.

Jasanoff J. 1978 Stative and middle in Indo-European. - Innsbruck.

Kortlandt F. 1974 Old Prussian accentuation. - KZ, Bd. 88, S. 299-306. 1977 Historical laws of Baltic accentuation. - Baltistica, t. 13(2), p. 319-330. 1978 On the history of the genitive plural in Slavic, Baltic, Germanic, and Indo-European. - Lingua, No 45, p. 281-300. 1979a Toward a reconstruction of the Balto-Slavic verbal system. - Lingua, No 49, p. 51-70. 1979b The Old Irish absolute and conjunct endings and questions of relative chronology. - Ériu, No 30, p. 35-53. 1979c On the history of the Slavic nasal vowels. - IF, Bd. 84, S. 259-272.

Lane G. S. 1959 The formation of the Tocharian subjunctive. - Language, No 35, p. 157179.

Leskien A. 1907 Über slavisches $o$ in Endsilben. - IF, Bd. 21, S. 335-338.

Matusevičiūtė I. 1938 Prierašai Berlyno valstybinès bibliotekos Sengstacko originale. APh, t. 7, p. 88-101.

Pedersen H. 1921 Les formes sigmatiques du verbe latin et le problème du futur indo-européen. - København. 1933 Études lituaniennes. - København.

Schmalstieg W. R. 1958 The vocalism of the Lithuanian sigmatic future. - The Slavic and East European Journal, No 16, p. 120-129.

Schmid W. P. 1963 Studien zum baltischen und indogermanischen Verbum. - Wiesbaden.

Stang C. S. 1957 Slavonic Accentuation. - Oslo. 1966 Vergleichende Grammatik der baltischen Sprachen. - Oslo.

Van Wijk N. 1918 Altpreussische Studien. - Haag. $1929 \mathrm{Zu}$ den alpreussischen Personalendungen -ai, -ei. - IF, Bd. 47, S. 148-160.

Zinkevičius Z. 1966 Lietuvių dialektologija. - V. 